\title{
Errata
}

\section{Construction of a Representative Genomic Library from a Hexaploid Wheat ${ }^{1}$}

\author{
S.A. Filichkin, A.P. Tikhonov, and A.A. Yephremov \\ Department of Genetics and Biotechnology, Krasnodar Center of Agricultural \\ Biotechnology, 350012 Krasnodar-12, U.S.S.R.
}

\begin{abstract}
The large genome size and the great amount of DNA repeats make it rather diffiult to obtain a representative hexaploid wheat genomic library. The protocol is given with modifications to phage isolation and to purification of vector and plant DNAs by electrophoresis in low-concentration SeaKem agarose gels. Representative genomic libraries of the soft wheat variety carrying a translocated rye chromosome are 1RS were constructed in a recD-minus $E$. coli strain to reduce recombinational loss.
\end{abstract}

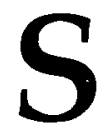

uccessful construction of a representative library of plant genomic DNA, depends not only on DNA purity and freedom from polysaccharides and other contaminants but also on the ability to minimize recombinational loss of repeated sequences (Frischauf etal., 1983; Fedoroff, 1985; Wyman et al., 1986). In the case of plants such as hexaploid wheat, the large genome size and the presence of repeated sequences make it difficult to obtain a representative library. Modifications to the standard phage isolation procedure can improve DNA purity, while the use of a recD-minus strain of $E$. coli (TAP90) can reduce recombinational loss. The fractionation of DNA digests in the density gradients is a labor-intensive and time-consuming procedure. As a simple and rapid alternative, we separate the vector and insert DNA fragments by electrophoresis in lowconcentration agarose gels. Several representative genomic libraries of the soft wheat variety Aurora were generated using these approaches.

Abbreviations: $\mathrm{E} \mathrm{Br}$, ethidium bromide; $\mathrm{PEG}$, polyethylene glycol; $\mathrm{SM}, \mathrm{TAE}, \mathrm{TE}$ and TM are defined in Materials Required.

'Erratum: This is a corrected version of an article that appeared in the Plant Molecular Biology Reporter 8(2):85-91. 


\section{Materials Required}

\section{Bacterial strains and phage vector}

EMBL4 lambda replacement vector (Frischauf et al., 1983) and E. coli host strains TAP90 (Patterson \& Dean, 1987) and K803 (Wood, 1966) were used.

\section{Solutions required}

$10 \mathrm{M}$ ammonium acetate, filtered through a $0.22 \mu \mathrm{m}$ membrane buffer 1: $25 \mathrm{mM}$ Tris $\mathrm{HCl} \mathrm{pH} 7.6,0.4 \mathrm{M}$ sucrose, $2 \mathrm{mM} \mathrm{CaCl}, 0.05 \%$ (w/v) 1-octanol, $2 \mathrm{mg}$ polyvinylpyrrolidone/mL (PVP-360, Sigma), $0.4 \mathrm{mg} \mathrm{EtBr} / \mathrm{mL}$

buffer 2: $10 \mathrm{mM}$ Tris $\mathrm{HCl}$ pH 7.5, 0.2 sucrose, $2 \mathrm{mM} \mathrm{CaCl}_{z}, 0.1 \%$ (v/ v) Triton $X-100$

electroelution buffer: $20 \mathrm{mM}$ Tris $\mathrm{HCl}$ pH 3.0, $0.1 \mathrm{mM}$ EDT A, $5 \mathrm{mM}$ $\mathrm{NaCl}, \mathrm{pH} 8.0$

ligase buffer: $66 \mathrm{mM}$ Tris $\mathrm{HCl} \mathrm{pH} 7.6,6.6 \mathrm{mM} \mathrm{MgCl}, 10 \mathrm{mM}$ dithiothreitol

PEG 8000, 10\% (Sigma Chemicals, St. Louis, MO)

PEG 6000, $12 \%(w / v)$

SeaKem agarose, $0.3 \%$ (FMC Bioproducts, Denmark)

SM: $10 \mathrm{mM} \mathrm{NaCl}, 10 \mathrm{mM} \mathrm{MgSO}_{4}, 50 \mathrm{mM}$ Tris $\mathrm{HCl} \mathrm{pH} \mathrm{7.5,} \mathrm{0.01 \%}$ $(w / v)$ gelatin

TAE: 40 mM Tris-acetate $\mathrm{pH}$ 8.0,2 mM EDTA

TE: $25 \mathrm{mM}$ Tris $\mathrm{HCl} \mathrm{pH} 8.0,20 \mathrm{mM}$ EDTA

TM: $10 \mathrm{mM}$ Tris $\mathrm{HCl}$ pH 8.0, $10 \mathrm{mM} \mathrm{MgSO}_{4}$

\section{Procedure}

\section{Isolation of EMBL4 $\lambda$ DNA}

- Grow K803 host cells infected by lambda bacteriophage until lysis is complete. After DNAase and RNAase treatment, precipitate phage particles overnight at $0^{\circ} \mathrm{C}$ with $10 \%$ PEG 8000 . Collect by centrifugation at $5000 \mathrm{~g}$ at $2^{\circ} \mathrm{C}$ for $20 \mathrm{~min}$.

- Resuspend the pellet in $4 \mathrm{MCsCl}$ in SM buffer and leave overnight at $4^{\circ} \mathrm{C}^{1}$ Dilute the suspension with $\mathrm{SM}$ to $1 \mathrm{M} \mathrm{CsCl}$ and centrifuge (10,000 g at $4^{\circ} \mathrm{C}$ for $10 \mathrm{~min}$ ).

- Discard the pellet and repeat polyethylene glycol precipitation step. 
- Layer $3 \mathrm{~mL}$ of the phage suspension in $1 \mathrm{M} \mathrm{CsCl}$ on a step gradient of $\mathrm{CsCl}$ composed of $12 \mathrm{~mL} 1.45 \mathrm{~g} / \mathrm{mL}, 10 \mathrm{~mL} 1.5 \mathrm{~g} / \mathrm{mL}$, and $5 \mathrm{~mL}$ $1.7 \mathrm{~g} / \mathrm{mL}$, and centrifuge at $80,000 \mathrm{~g}$ for $2 \mathrm{~h}$ at $20^{\circ} \mathrm{C}$.

- Collect the phage band, adjust the density with solid $\mathrm{CsCl}$ to 1.75 $\mathrm{g} / \mathrm{mL}$, and place on the bottom of 30-mL tube. Overlay with $\mathrm{CsCl}$ solutions $(10 \mathrm{~mL} 1.7 \mathrm{~g} / \mathrm{mL}, 10 \mathrm{~mL} 1.50 \mathrm{~g} / \mathrm{mL}$, and $5 \mathrm{~mL} 1.45 \mathrm{~g} / \mathrm{mL})$ and repeat centrifugation. ${ }^{2}$

- Collect the band with phage particles and dialyze against a buffer containing $10 \mathrm{mM}$ Tris $\mathrm{HCl} p \mathrm{H} 8.0,10 \mathrm{mMNaCl}$, and $10 \mathrm{mMMgSO}_{4}$ for $2 \mathrm{~h}$.

- Digest the phage with $40 \mathrm{mg} / \mathrm{mL}$ of Proteinase K in $0.5 \%$ SDS, 20 $\mathrm{mM}$ EDTA at $37^{\circ} \mathrm{C}$ for $0.5 \mathrm{~h}$; extract sequentially with phenol, phenol/chloroform, and chloroform; precipitate with 2 vols ethanol; and make $2 \mathrm{M}$ in ammonium acetate.

- Digest the phage DNA with a three-fold excess of BamHI (Ferment, Vilnius, U.S.S.R); extract with phenol/chloroform; adjust to $2.5 \mathrm{M}$ ammonium acetate, and precipitate with ethanol.

\section{Isolation of wheat nuclear DNA}

- Sterilize wheat seeds with $0.1 \%$ silver nitrate at room temperature for $30 \mathrm{~min}$ and germinate under sterile conditions in the dark.

- Freeze two-week-old seedling shoots in liquid nitrogen, grind with mortar and pestle, and transfer $30 \mathrm{~g}$ of the powder into $300 \mathrm{~mL}$ of freshly prepared, ice-cold buffer 1 (modification of Kislev \& Rubenstein, 1980).

- Homogenize thoroughly and filter through 100 - and $40-\mu \mathrm{m}$ stainless steel screens.

- Centrifuge filtrate at $400 \mathrm{~g}$ for $15 \mathrm{~min}$ at $2^{\circ} \mathrm{C}$. Resuspend the pellets in $50 \mathrm{~mL}$ of buffer 2 and centrifuge at $400 \mathrm{~g}$ for $10 \mathrm{~min}$. Repeat washing twice, resuspending the pellet in $50 \mathrm{~mL}$ of buffer 2 without Triton X-100.

- Resuspend nuclei in $10 \mathrm{~mL}$ of ice-cold TE, add sodium $\mathrm{N}$ lauroylsarcosine to $0.5 \%$ and proteinase $\mathrm{K}$ to $100 \mu \mathrm{g} / \mathrm{mL}$. Digest for $1 \mathrm{~h}$ at $37^{\circ} \mathrm{C}$.

- Centrifuge at $5000 \mathrm{~g}$ for $15 \mathrm{~min}$ and discard the pellet.

- Add $1 \mathrm{~g} / \mathrm{mL}$ of solid $\mathrm{CsCl}$ and $100 \mu \mathrm{g} \mathrm{EtBr} / \mathrm{mL}$ to the supernatant. Centrifuge at $200,000 \mathrm{~g}$ at $20^{\circ} \mathrm{C}$ for $24 \mathrm{~h}$.

- Collect the pink band of DNA and remove EtBr by extraction with isopropanol or butanol (Watson \& Thompson, 1986).

- Microdialize 300- $\mu$ l portions in Eppendorf tubes with lids removed (Overall, 1987). Precipitate with two volumes of ethanol; dissolve in TE, without complete drying of the pellets; store at $4^{\circ} \mathrm{C}$. 
Partial restriction of wheat DNA

- Establish the optima! concentration of Sau3A I for producing the maximum number of $20-\mathrm{kb}$ fragments of wheat DNA by digesting with various amounts of the enzyme (Maniatis et al., 1982). Digest 50 to $100 \mu \mathrm{g}$ of DNA with this optimal concentration of Sau3A I.

- Extract with phenol-chloroform (1:1) and chloroform, precipitate with ethanol, dissolve in 50 to $100 \mu \mathrm{l}$ of water, and store at $-20^{\circ} \mathrm{C}$.

DNA purification by agarose-gel electrophoresis

- Boil $0.3 \%$ SeaKem agarose in TAE buffer for $5 \mathrm{~min}$ while stirring. Cool the gel for $30 \mathrm{~min}$ before use at $4^{\circ} \mathrm{C}$. Load $10 \mu \mathrm{g}$ of partially digested wheat DNA per well and $1 \mu \mathrm{g}$ of $B g$ III-digested $\lambda$ in wells at each side of the gel.

- After electrophoresis for $3 \mathrm{~h}$ at $4 \mathrm{~V} / \mathrm{cm}$, stain marker lanes by immersing the edges of the gel in a solution of $0.5 \mu \mathrm{g} \mathrm{EtBr} / \mathrm{mL}$.

- Excise gel slices in the range 13 to $22 \mathrm{~kb}$ as determined by the $\lambda$ markers and soak them for $1 \mathrm{~h}$ at $4^{\circ} \mathrm{C}$ in electroelution buffer.

- Electroelute DNA for $1 \mathrm{~h}$ with IBI model UEA (International Biotechnologies, New Haven, Connecticut, USA) or a similar Vchannel electroelution device using a cushion of $10 \mathrm{M}$ ammonium acetate cushion without bromphenol blue. Recover DNA by precipitation with 2 volumes of ethanol at $-20^{\circ} \mathrm{C}$ overnight.

- Purify left and right $\lambda$ arms (19 and $9 \mathrm{~kb}$ ) as described above, except heat DNA at $65^{\circ} \mathrm{C}$ for $5 \mathrm{~min}$ and cool on ice before loading. Use HindIII $\lambda$ as markers.

\section{Ligation of intact vector and donor DNA}

Mix BamHI-cleaved EMBL4 DNA and $1 \mu \mathrm{g}$ wheat DNA partially restricted with Sau3AI in the proportions 1:2, 1:1, 2:1 in 10 $\mu$ l of ligase buffer (Maniatis et al., 1982) with 4 to $8 \mathrm{U}$ of T4 DNA ligase. Incubate at $12^{\circ} \mathrm{C}$ for $16 \mathrm{~h}$, precipitate with ethanol, and dissolve in $3 \mu \mathrm{l}$ of TM.

\section{Ligation of separated vector arms and donor DNA}

- Mix equimolar amounts of $\lambda$ left and right arms (approximately 0.7 and $0.3 \mu \mathrm{g}$ ) and $0.7 \mu \mathrm{g}$ of agarose-fractionated wheat DNA. The optimal ratio of vector to insert should be experimentally estimated for every lot of DNA). Ligate in the presence of $12 \%(\mathrm{w} / \mathrm{v})$ PEG 6000 as described for the intact vector. Add $2 \mu \mathrm{l}$ of $5 \mathrm{M} \mathrm{NaCl}$ and precipitate DNA overnight at $0^{\circ} \mathrm{C}$.

- Collect the pellet by centrifugation at $7000 \mathrm{~g}$ for $10 \mathrm{~min}$, remove all traces of the ligation mixture and dissolve in $3 \mu \mathrm{l}$ of TM buffer.

- Package DNA in vitro according to Maniatis et al. (1982) or to the 
instructions of the packaging extracts manufacturer. Hybridize the sets of 200 to 300 plaques to Sau $3 \mathrm{AI}$-digested, nick-translated wheat DNA.

- Isolate DNA from 10 to 20 individual plaques (cf. Grossberger, 1987), digest with PvuII, and analyze on $0.9 \%$ agarose.

\section{Notes}

1. This step significantly increases the yield (Latchman and Brickell, 1986).

2. Consequent purification of bacteriophage from the top to bottom of a step gradient and vice versa allows one to avoid the time-consuming process of equilibrium gradient centrifugation.

\section{Results and Discussion}

Wheat DNA was partially digested with the Sau $3 \mathrm{AI}$, ligated into the $\lambda$ vector, and packaged as described in brochure. Plating efficiencies obtained for various combinations of vector and insert DNA packaged in vitro are shown in Table 1 . The vector DNA was cleaved at the Bam $\mathrm{H} 1$ cloning sites almost completely since on packaging of unligated DNA the plating efficiency was $<0.02 \%$ that of intact phage DNA. After religation the plating efficiency rose 300 fold.

The highest recombinant plating efficiency was obtained when BamHIcut vector was ligated to unfractionated, partially digested wheat DNA. A comparison of this value with that of self-ligated BamHI-cut shows

Table 1. Plating efficiencies.

\begin{tabular}{|c|c|c|c|}
\hline EMBL4 Vector DNA & Insert DNA & $\begin{array}{c}\text { p.f.u./ } / \mu g \\
\text { vector DNA }\end{array}$ & $\begin{array}{c}\text { p.f.u. } / \mu g \\
\text { donor DNA }\end{array}$ \\
\hline Intact & none & $5.0 \times 10^{7}$ & \\
\hline BamH1-cut & none & $8.0 \times 10^{3}$ & \\
\hline Bam $\mathrm{H} 1$-cut, religated & none & $2.5 \times 10^{6}$ & \\
\hline BamH1-cut & partial Sau3A I & $2.5 \times 10^{7}$ & $2.0 \times 10^{7}$ \\
\hline $\mathrm{BamH} 1-\mathrm{cut}+\mathrm{Co}\left(\mathrm{NH}_{3}\right)_{6} \mathrm{Cl}_{3}$ & partial Sau3A I & $2.5 \times 10^{7}$ & $2.0 \times 10^{7}$ \\
\hline BamH1 arms* & none & 0 & \\
\hline BamH1 arms* & partial Sau3A I* & $7.5 \times 10^{4}$ & $1.0 \times 10^{5}$ \\
\hline
\end{tabular}




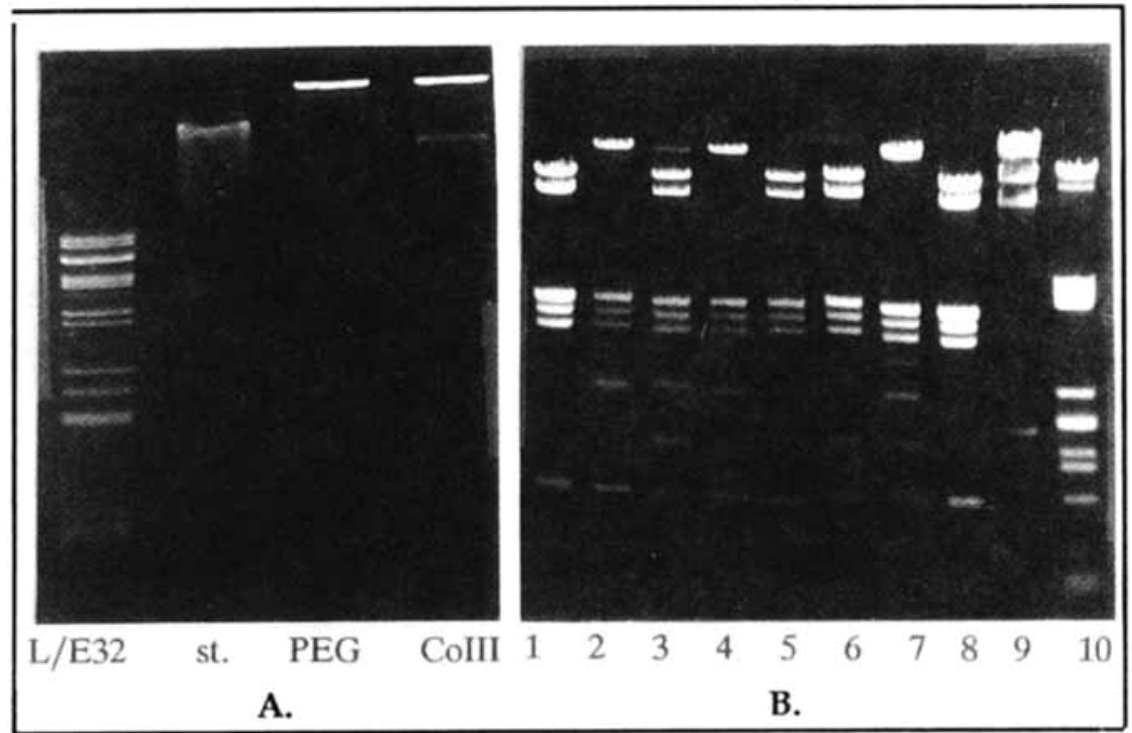

Fig. 1. A. Effect of the presence of PEG 6000 and Co(III) on blunt-end ligation. L/E32, $\lambda$ DNA digested with Eco32I (Ferment, Vilnus, U.S.S.R.), an EcoRV isoshizomer, before ligation; st., standard ligation conditions; $P E G$, ligation in the presence of $12 \%(\mathrm{w} / \mathrm{v})$ PEG 6000 ; CollI, ligation in $1 \mathrm{mM} \mathrm{Co}(\mathrm{NH}) . \mathrm{Cl}$. $\mathrm{B}$. Restriction patterns of DNA from randomly selected positive plaques of wheat library. E, PvuII-cleaved EMBL4 DNA; B, BglII-cleaved $\lambda$ DNA; P, PstIcleaved $\lambda$ DNA.

that the background of non-recombinant phages does not exceed $10 \%$. This allows the library to be screened directly without amplification under selective conditions. The presence of cobalt hexamine chloride improved the blunt end ligation significantly (Fig. 1A) but had no effect on the plating efficiency when ligating vector and inserts with cohesive ends. Plating efficiency in the latter case was approximately $50 \%$ of that of uncut EMBL4 vector.

The use of separated vector arms in place of intact vectors gave a significantly different and potentially more useful result. Ligation of fractionated donor DNA and vector arms gave 300 times fewer plaques than when unfractionated fragments were used. Nevertheless, the complete absence of background in the control experiment (religated arms) indicated that almost all plaques arising from the use of separated arms were recombinant. This was confirmed both by hybridization and restriction analysis. A randomly selected set of 200 plaques all hybrid- 
ized with a [32P]-labelled wheat DNA (data not shown). PvuII digestion of DNA isolated from 14 randomly chosen plaques, from the set of 200 (Fig. 1B) showed that most of them had different restriction patterns.

The haploid wheat genome contains $1.7 \times 10^{10} \mathrm{bp}$. In order to prepare a representative library of $20 \mathrm{~kb}$ inserts, it is necessary to generate about $3.9 \times 10^{6}$ clones $(\mathrm{P}<0.01)$ (Kaiser \& Murray, 1985). This number was exceeded when wheat DNA was ligated to Bam HI-cut vector and the library was used directly for screening. Although the library obtained from the use of separated vector arms DNA cannot be considered representative, the absence of background plaques is attractive. The simplicity of the method allows the routine generation of libraries as needed when searching for a desired gene. According to Fedoroff (1985), it is necessary to screen about $10^{5}$ recombinant phages when searching for a clone carrying a unique gene in a maize library. This number may be lowered when searching for repeated sequences or multigene family members.

Plant genomes generally contain large numbers of repeated sequences that may cause recombinational instability when cloned (Kaiser \& Murray, 1985). For this reason, amplification of the library was avoided and the libraries were constructed in the host strain E. coli TAP90, which carries a mutation in recD (Patterson \& Dean, 1987). This mutation has been shown (Wyman et al., 1986) to reduce the losses of recombinant phage clones from genomic libraries. TAP90 was also used for DNA minipreps from the individual plaques.

The wheat variety Aurora carries a translocated rye chromosome arm and has therefore some positive and negative agronomic traits (Koebner \& Shepherd, 1986). Rye DNA sequences from this translocation may be isolated from genomic libraries by probing with rye-specific sequences. These rye translocation-specific sequences may be used for 1RS arm mapping and gene cloning. Several clones were isolated from the EMBL4 library by hybridization with different rye-specific probes and are currently being characterized.

Acknowledgments: We wish to thank Dr. T.A. Patterson (National Cancer Institute, Maryland, U.S.A.) for E. coli strain TAP90, Drs. S. Mechedov and M. Golovkin (Institute of General Genetics, Moscow, U.S.S.R.) for packaging extracts and discussion of the methods, Drs. R.O. Morris and C.L. Mclntyre (University of Missouri-Columbia,U.S.A.) for the useful discussion in the preparation of the manuscript. 


\section{References}

Fedoroff, N. 1985. Biochemical and molecular techniques in maize research. In: Genetic engineering. Principles and methods. Vol. 7. ed. by J.K. Setlow, Plenum Press, N.Y. \& London.

Frischauf, A.M., H. Lehrach, A. Poustka and N. Murray. 1983. Lambda replacement vectors carrying polylinker sequences. J. Mol. Biol. 170:827-842.

Grossberger D. 1987. Minipreps of DNA from bacteriophage lambda. Nucl. Acids Res. 15:6737.

Kaiser, K. and N.E. Murray. 1985. The use of phage lambda replacement vectors in the construction of representative genomic DNA libraries. In: DNA Cloning. A Practical Approach. Volume 1. ed. D.M. Glover, IRL Press, Oxford.

Kislev, N. and I. Rubenstein. 1980. Utility of ethidium bromide in the extraction from whole plants of high molecular weight maize DNA. Plant Physiol. 66:1140-1143.

Koebner, R.M.D. and K.W. Shepherd. 1986. Controlled introgression to wheat of genes from rye chromosome arm 1 RS by induction of allosyndesis. Theor. Appl. Genet. 73:197-208.

Latchman, D.S. and P.M. Brickell. 1986. An improved method for the isolation of high yield of bacteriophage lambda DNA. Nud. Acids Res. 14:9220.

Maniatis, T., E.F. Fritsch and J. Sambrook. 1982. Molecular Cloning: A Laboratory Manual. Cold Spring Harbor Laboratory, New York.

Overall, C.M. 1987. A microtechnique dialysis of small volume solutions with quantitative recoveries. Anal. Biochem. 165:208-214.

Patterson, T.A. and M. Dean. 1987. Preparation of high titer lambda phage lysates. Nud. Acids Res. 15:6298.

Watson, J.C. and W.F. Thompson. 1986. Purification and restriction endonuclease analysis of plant nuclear DNA. In: Meth. Enzymol. 119:57-75.

Wood, W.B. 1966. Host specificity of DNA produced by Escherichia coli: Bacterial mutations affected by restriction and modification of DNA. J. Mol. Biol. 16:118-132.

Wyman A.R., K.F. Wertman, D. Barker, C. Helms and W.H. Petri. 1986. Factors which equalize the representation of genome segment in recombinant libraries. Gene. 49:263271.

\section{Erratum}

Report of Meeting: VIth NATO Advanced Study InstitutePlant Genomes. Plant Mol. Biol. Report. 8(3):186-198.

p. 190. The sequence defined as ABRE by John Mundy (Copenhagen) should read TACGTGGC not GTGACTGGC as reported. 